\title{
Assessment of Pastorals' Perceptions of Lake Basaka's Water Quality Concerning Its Impact on Sheep and Goat Production in Mid Rift Valley of Ethiopia
}

\author{
Diriba Tulu ${ }^{12}$ \\ ${ }^{1}$ Afric center of excellence for Climate Smart Agriculture and Biodiversity Conservation, Haramaya University, \\ P.O.Box. 138, Dire Dawa, Ethiopia \\ ${ }^{2}$ School of Animal and Range Sciences, Haramaya University, P. O. Box. 138, Dire Dawa, Ethiopia \\ Mengistu Urge \\ School of Animal and Range Sciences, Haramaya University, P. O. Box. 138, Dire Dawa, Ethiopia \\ Yisehak Yusuf \\ School of Animal and Range Sciences, Haramaya University, P. O. Box. 138, Dire Dawa, Ethiopia
}

\begin{abstract}
The aim of this study was to assess pastoral perceptions of lake Basaka saline water concerning the effects on sheep and goat production in great Ethiopia's mid-rift valley. Fourteen focus group discussions with livestock owners and 15 key informant interviews were done in selected areas, and both quantitative and qualitative data were collected using a questionnaire guide. The survey study report showed that pastoral and agropastoral were common production systems with diverse species of livestock with goat and sheep in dominance. Feed scarcity, drought, and water problems were the major constraints to sheep and goat production and productivity. While lake Basaka water is not good for the drinking of sheep and goats because of its salinity content, it was a major water source for their animals, especially during dry seasons. Seasons and climate conditions were varied the salinity contents of lake Basaka water and had negative effects on livestock production and health. However, goats are more tolerant of the drinking lake Basaka than sheep in the study area. Based on the pastoral perceptions, in dry regions including the study area, where feed is scarce both in quantity, long-term drinking naturally saline water of lake Basaka is not safe for livestock species, especially during dry seasons. These findings are useful for policymakers and organizations working on projects aimed at increasing the resilience of pastoralists, while future research could identify appropriate technologies to help alleviate these impacts.
\end{abstract}

Keywords: Water scarcity; poor water quality; small ruminants

DOI: $10.7176 / \mathrm{JBAH} / 11-17-02$

Publication date:September $30^{\text {th }} 2021$

\section{Introduction}

The production of small ruminants contributes to the livelihood of pastoral communities, although it is constrained by many factors (Abdilatif et al., 2018). Ethiopia has a diverse range of native sheep and goat breeds, with a population of 42.9 million sheep and 52.5 million goats (CSA (Central Statistic Authority), 2021). Furthermore, the country has a diverse climate that makes it suitable for the support of a large number and a species of livestock (Funk et al., 2012). However, in most pastoral and agropastoral areas of the country, the livestock sector is affected by climate change and variability, which has a greater influence on water availability and quality (Adem \& Bewket, 2011). Furthermore, freshwater contamination as a result of global warming is a critical issue for the world in many arid and semi-arid countries, including Ethiopia (Jiménez Cisneros et al., 2015).

Increasing competition over freshwater resources, combined with continuous quality deterioration, is posing a serious problem in many developing countries, including Ethiopia, where technical, socioeconomic, and political factors are impeding proper resource exploitation (Amenu, 2013). Thus, lake water playing a significant source of drinking and other domestic purposes, and also being affected by climate change and its ecological response will become more pronounced in the future (Jeppesen et al., 2014; Jiménez Cisneros et al., 2015). Lake Basaka is located in Ethiopia's Mid Rift Valley, where water scarcity and low quality are common, and it serves as a supply of domestic water, particularly during the dry seasons (Ayenew, 2007; Dinka, 2017). It is expanding at a rapid and dramatic rate with its poor water quality (EC 6.3dSm-1, SAR 300, and $\mathrm{pH}=9.6)$ is expected to have a variety of negative effects on the region's surface- and groundwater dynamics and soil properties, which is especially dangerous for the sustainability of agricultural development. (Dinka, 2012a; Dinka, 2012b)

As the result, understanding the perceived risk and incorporating this information into the policymaking process requires an analysis of farmers' perceptions of the quality of their water sources (Woldetsadik et al., 2018). Farmers also have a thorough understanding of many of the relationships that exist between animals and 
their surroundings, notably those involving grazing and shelter-seeking behavior (Komwihangilo et al., 2001). Therefore, the purpose of this study was to assess pastoral perceptions of lake Basaka saline water concerning sheep and goat production in Ethiopia's mid-rift valley.

\section{Materials and Methods}

Study area

Fentalle is located in the great Ethiopian mid-rift valley between $8^{\circ} 45^{\prime} \mathrm{N}$ and $39^{\circ} 50^{\prime} \mathrm{E}$, in a tropical climate zone. It is 193 kilometres east of Addis Ababa on the Djibouti highway. Its elevation ranges from $1500 \mathrm{~m}$ to $2000 \mathrm{~m}$. The District climate is classified as Hot-semi Arid, with steep vegetation, less fall, and coarser grasses. Lake Basaka which is characterized by rapidly expanding saline water is also a source of surface water with limited use for some parts of the study area (Lemessa, 2011).

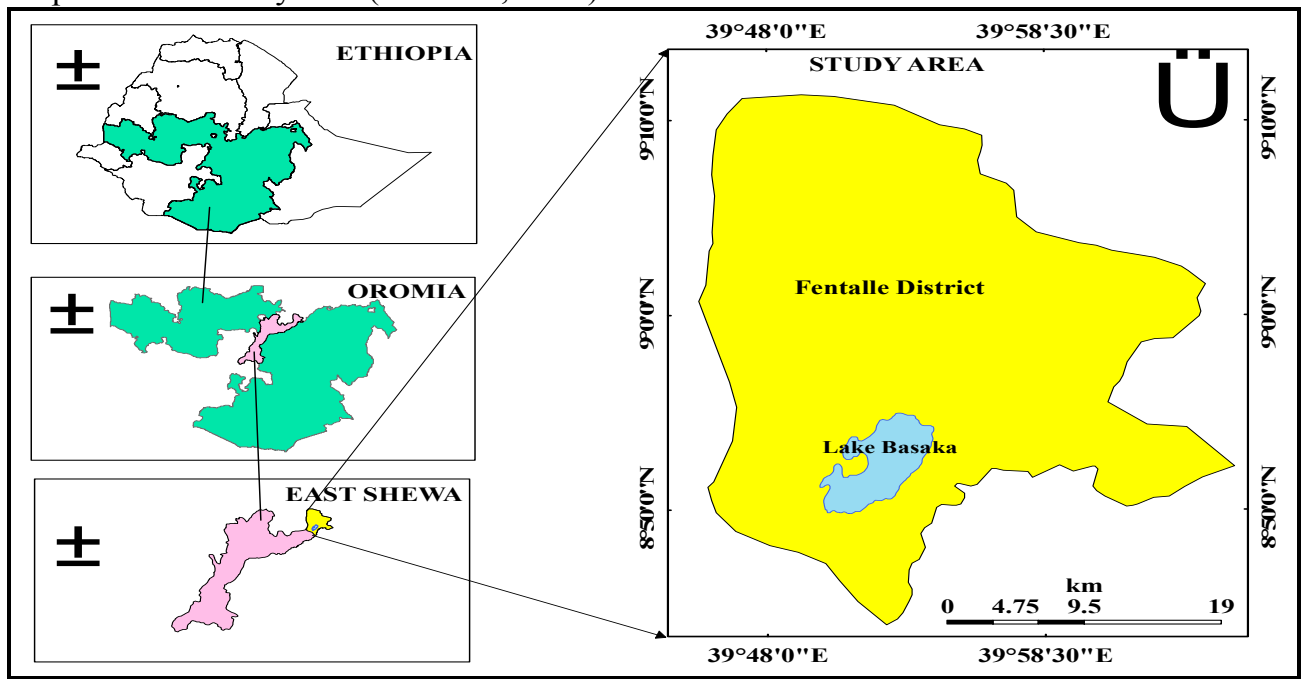

Figure 1. Map of the Fentalle district

\section{Household selection and data collection}

A cross-sectional study design was used to collect data about goat's and sheep's perceptions of the effects of drinking saline water from Lake Basaka. Households were selected based on their ownership of goats and sheep, their nearness to the lake Basaka water source, and their use of the lake water for drinking goats and sheep. Fourteen focus group discussions with livestock owners and 15 key informant interviews were used. Household heads, sheep and goat keepers, and elderly community members were identified for the interviews. Key informants and agricultural extension officers provided secondary data on livestock species kept, water sources, and water availability comparisons over the previous years. Transect walks were conducted in grazing areas and different water sources for each village/group of villages, and vegetation grazed and browsed, as well as water availability for goats drinking, were observed and recorded. The questionnaire covered topics such as household demography, sheep and goat production, owners' perceptions of the effects of Lake Basaka water on livestock production, water accessibility, and quality.

\section{Data Analysis}

The Statistical Package for Social Sciences was used to analyse the data collected through questionnaires (SPSSv-23). For socio-demographic variables, descriptive summary statistics such as mean, percentage, and frequencies were calculated and displayed in table and bar graphs. The null hypothesis states that the response frequencies for the various answer options and socio-demographic factors are the same.

\section{Results and Discussion}

Households' socio-economic characteristics

As shown in Table 1, most interviewed household heads were male, relatively younger households were sampled and this may increase the relevance of the data because youngers are more active and involved in daily farming activities and easily understand the question to answer. The majority of household respondents were married and the literacy rate was high and only about $26 \%$ were literate. This may be a bottleneck regarding the perception of water quality and salinity, veterinary care, production system, feeding as well as marketing strategies since they have no modern education on livestock systems to perform their farming in modern ways. 


\section{Livestock production systems in the study area}

Pastoralism and agropastoral livestock production systems were the dominant systems in the study area (Table 1). Additionally, the main sources of income were the sale of livestock, livestock products, and crop production in that order. This result agreed with the report of (Abdulatife \& Ebro, 2015) who noted that the main sources of income for Afar pastoralists were the sale of livestock and their products and as well as crop production. and livestock sales are the major income source. Similarly, camels, sheep, goats, and cattle are the most common livestock among Karrayyu pastoralists, and livestock sales provide the majority of their cash income. According to studies, livestock production is the primary source of income for pastoralists, serving as a food, financial, social, and physical asset, a store of wealth, and a cornerstone for social relationships. ((Pantuliano and Pavanello, 2009; Berhanu and Fayissa, 2010).

\section{Purpose of keeping sheep and goats}

Sheep and goat production play an important role in man's life in a variety of ways, whether in rural or urban areas. In the current study, the majority of household respondents kept goats and sheep as a source of money to supplement the family income, followed by milk and meat for home consumption (Figure 2). Furthermore, communities in the study sites kept goats and sheep as gifts for relatives and children, and traditional ceremonies are common practices performed in celebration of a specific event. In Ethiopian traditional religion, the Karrayyu and Ittu tribal groups of the Oromo people slaughter sheep and/or goats before proceeding to any other acts of the event to sacrifice and express gratitude to their ancestors. The present report is in agreement with (Gebeyehu et al., 2013) who reported that the primary reason for keeping goats at Fentalle was to generate income, followed by milk and meat for home consumption. The selection of suitable species is regarded as one method of increasing livestock contribution to households (Devendra, 2001). Goats and sheep were the first choices of species for regular and emergency cash needs as they are fast breeders, reliable to produce in harsh environments, and relatively cheap to acquire. The multiple objectives of keeping goats and sheep were also reported in previous studies in Ethiopia (Solomon et al., 2010). Although all households across production systems had multiple objectives, households in pastoral and agropastoral systems had relatively better interests for the intangible benefits of small ruminants (Tadesse et al., 2014).

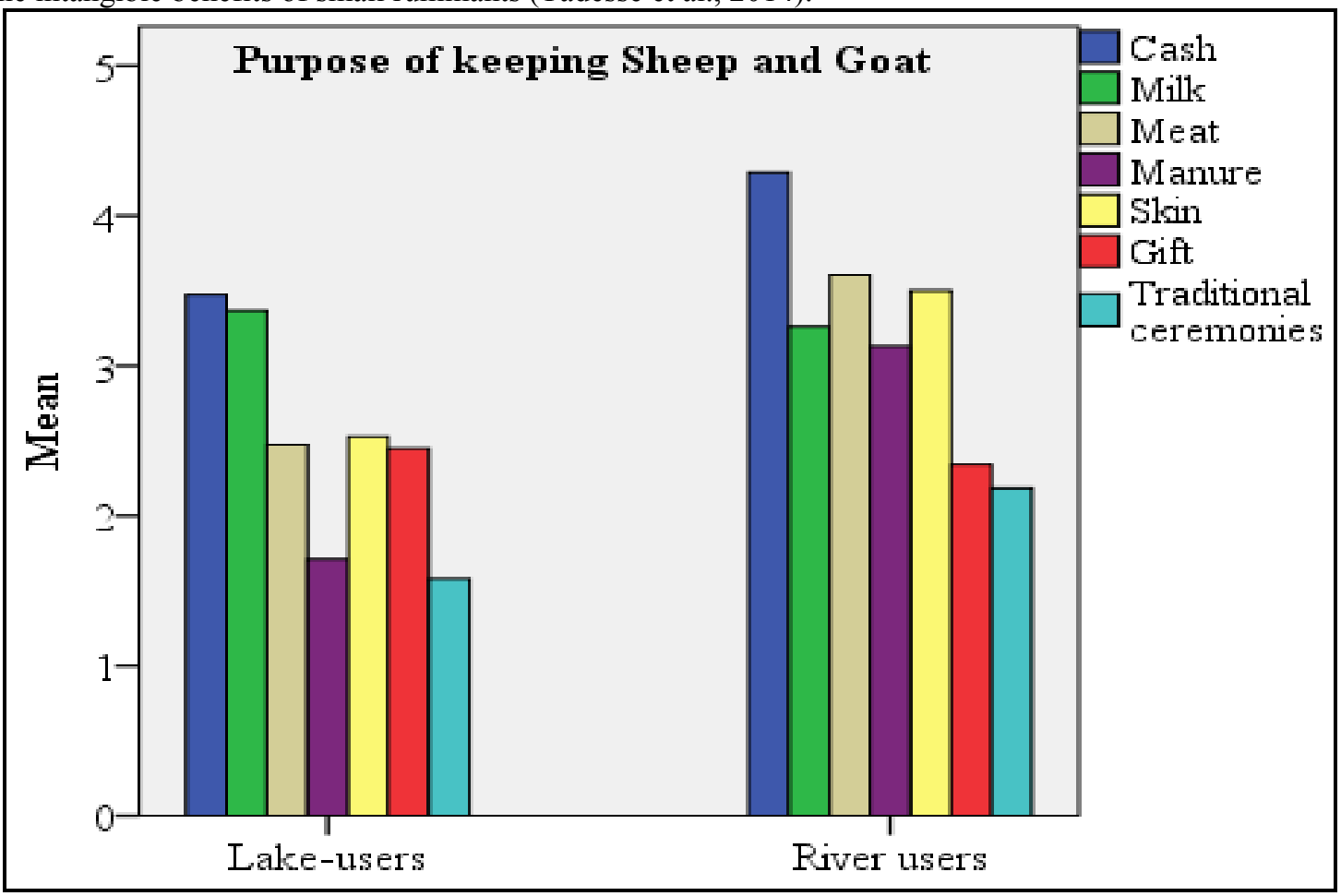

Figure 2. Purpose of keeping sheep and goats

\section{Major constraints to sheep and goat's production}

Figure 3 shows that feed scarcity was the most significant constraint to sheep and goat production in the study areas, followed by disease, drinking water scarcity, and quality. The current finding was similar to that of (Gebeyehu et al., 2013) who found that goat production in the Fentalle district was hindered by a severe feed shortage, high disease prevalence, high predatory, poor market, genetically less productive breed, severe water shortage, and a severe labour shortage for animal herding. In other parts of Ethiopia, the most significant 
constraints to sheep and goat production have been identified as a lack of feed, disease prevalence, and a scarcity of water (Solomon et al., 2010). Correspondingly, Bishu et al (2012) indicated that a critical constraint to livestock production is a lack of feed, water, and recurring drought, primarily due to drought and invading plants. Partinium (local name Ali ware) covered most of the rangeland in the current study area, causing feed shortages and shrinking of the rangeland, and water scarcity was caused by the expansion of saline lake Basaka and sugar cane plantation, sedentary agriculture, and bush encroachment.

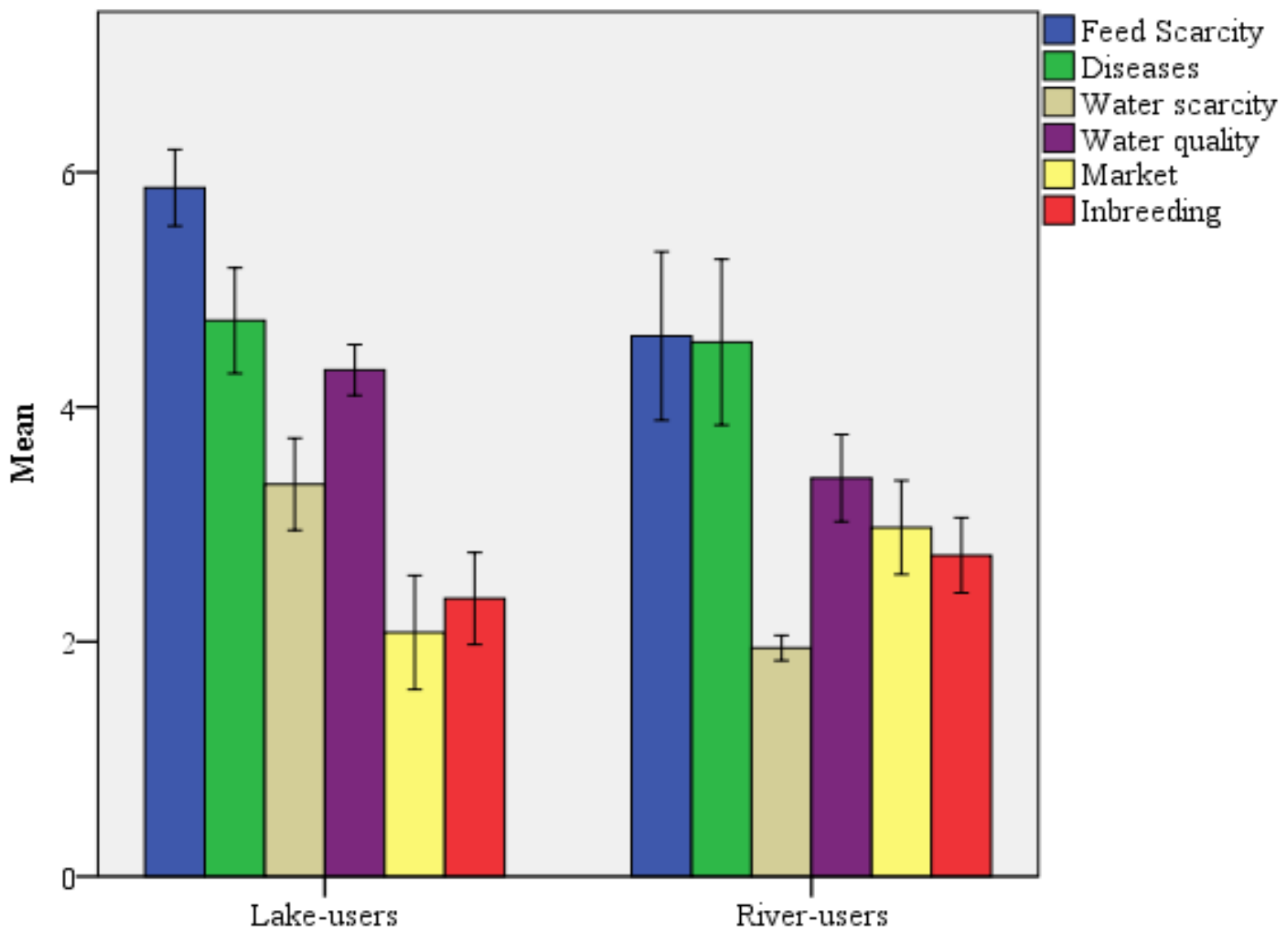

Figure 3. Major constraints of sheep and goat's production and productivity

\section{Sources and frequency of drinking water}

Throughout the year, rivers and Lake Basaka water were the primary sources of water for sheep and goats in the study sites (Table 2). However, the majority of lake Basaka users used solely lake Basaka water for their sheep and goats, especially during drought seasons. Furthermore, the majority of respondents across the surveyed sites stated that the distance of water sources was within one to three kilometres across all seasons of the year. About 51.5 percent of the household's respondents said their sheep and goats had free access to water, while others said they got it once or twice a day (Table 2). The frequency of watering suggests that the watering points were close to villages. Watering is not less common in this study compared to other studies. The higher watering frequency in the highland compared to the midland and lowland could be attributed to better access to nearby water sources (borehole). River systems, water sources, seasons, and a household's distance from the nearest water source were identified as major factors causing water scarcity for goats in resource-limited communal farming environments (Mdletshe et al., 2018).

\section{Seasonality of water scarcity and quality}

High seasonal variation in water availability is evident from the percentage of respondents utilizing different water sources for livestock drinking (Table 3). According to the respondent's sheep and goats, the production and productivity were challenged by water scarcity and quality, especially during cool and hot dry seasons. The chi-square test revealed that lake Basaka water users were more vulnerable to water scarcity and quality than non-lake Basaka water users. Pastorals' perceptions of water scarcity varied greatly between dry and wet seasons, with the majority of people experiencing water scarcity for livestock during the dry months of the year. (Amenu, 2013) stated that high seasonal fluctuation in water scarcity and quality was a pronounced problem of the communities, particularly during the dry season for livestock consumption, which can negatively affect livestock 
performance in Ethiopia's Rift Valley area. (Wagesho et al., 2012) showed that climate change, in the form of erratic rainfall and rising temperatures, is affecting the availability of water resources in Ethiopia's Rift Valley, including the study area. Respondents in this study area attributed water scarcity and poor quality of livestock drinking water to drought caused by climate change and variability, as well as the expansion of saline water in Lake Basaka.

\section{Trends and seasonal variation of Lake Basaka water quality}

Based on indicators of water salinity detection used by respondents, the majority of the respondents $(78.9 \%)$ perceived that lake Basaka water is a saline lake and at decreasing rate $(71.1 \%)$, especially during the summer season (

Table 4). However, the respondents stated the salinity contents of lake Basaka increases during cool dry (73.7\%) and hot dry $(90.8 \%)$ whereas it decreases during rainy $(75 \%)$ and post-rain $(64.5 \%)$ periods. Evidence from different physiochemical analyses indicated that lake Basaka water was experienced a sharp and fast decline in $\mathrm{EC}, \mathrm{Cl}^{-}, \mathrm{SO}_{4}, \mathrm{Na}^{+}$, and $\mathrm{K}^{-}$ions from the early 1960 s up to the late 1980 s. However, some parameters (e.g. Na, Ca, $\mathrm{Mg}, \mathrm{Cl}, \mathrm{SO}_{4}$ ) are showing an increment in recent years (Dinka, 2017).

The relatively stable or increasing ionic concentration of some parameters in the past 30 years may indicate the potential causes of pollution due to natural and anthropogenic sources (Ayenew, 2007; Klemperer and Cash, 2007; Dinka, 2012a; Fuad and Michael, 2019). In addition, the increment of lake Basaka water salinity during dry and hot seasons might be due to high evapotranspiration, lack of rainfall, drought, and climate change and variability. The salinity contents of lake Basaka water varied with seasons and climate conditions (Dinka, 2017; Fito, 2019).

\section{Effects of Drinking Saline Lake Basaka Water on Livestock Species}

As shown in Table 5 , all of the respondents stated that drinking Lake Basaka water has negative effects on livestock production, productivity, and health. The majority believe that small ruminants (sheep and goats) $(94.7 \%)$ and cattle $(82.9 \%)$ are severely affected, but the camel is relatively tolerant $(56.6 \%)$ indicating that camel is more adaptable to the drinking saline water of Lake Basaka followed by small ruminants. Animal tolerance to salinity changes according to species, age, water needs, and physiological conditions (Araújo et al., 2010). Camel tolerance is higher than sheep, goats, cattle, and horses, according to studies on sodium chloride in drinking water (Masters et al., 2007). This order of tolerance is consistent with an interrelationship between genetically determined low water turnover and salt tolerance suggested by (Squires, 1998).

\section{Effects of Drinking Saline Lake Basaka water on sheep and goat's production}

Table 5 presents the perception of the effects of drinking saline Lake Basaka water on sheep and goat's production and productivity in the study area. The majority of respondents perceived that drinking Lake Basaka water negatively impacted sheep and goat production and productivity. They stated that drinking Lake Basaka water reduces growth performance and milk yield, causes emaciation, health problems, and sometimes death of sheep and goats. Moreover, these problems were very serious especially during dry seasons because of drought and increased concentration of the Lake water (saline). Animals in arid and semi-arid areas may consume salt from several sources such as drinking saline water, feeding on saline plants, or from soils. The problem, especially if animals are under grazing conditions, is the accurate estimation of ingested salts in quantity and quality. The use of low-quality water can then have an impact on ruminant water and feed utilization, health, and production (NRC, 2007).

Drinking saline water increased the thirst feeling made an increase in water consumption which increases urination to help the kidney flush the harmful minerals (Masters et al., 2007). Also, controlled experiments reported that drinking saline water decreased feed intake in sheep (Yousfi \& Ben Salem, 2017), decreased average daily gain in goats (Mdletshe et al., 2017). Goats adapted to saline water, on the other hand, appear to be able to tolerate higher levels of salt than sheep (Mcgregor, 2004). The respondents noted that goats $(61.2 \%)$ were more tolerant than sheep (15.8\%) to the drinking of Lake Basaka saline water. The reason why the goat is more adaptable than sheep is related to feeding and drinking behavior. The goat has the behavior of less frequent drinking water and browsing herbs and shrubs while sheep drunk more water at once and graze grass growing around Lake Basaka which may contain high salt concentration. Because sheep panted more frequently than goats, the higher frequency of drinking events in sheep may be related to their evaporative cooling mechanisms. Due to " their longer fleece, sheep are perceived as having more water to regulate their body temperature, which increases their endogenous heat production (Al-Ramamneh et al., 2011).

\section{Conclusion}

Sheep and goats are predominantly kept by smallholder farmers and nearly all pastoralists and agropastoral, especially in semiarid and arid areas, where natural freshwater is limited, animals are forced to drink saline water. 
The majority $(100 \%)$ of the respondents perceived that Lake Basaka water was not good for livestock drinking because of its salinity, but it is the major water source for animals drinking, especially during the dry seasons. The salinity content of Lake Basaka varied with seasons and climate conditions which might negatively affect the production and health of animals. However, adaptability to the drinking water of Lake Basaka of livestock species was different within and between species, and goats are more adapted to drinking Lake Basaka water than sheep.

\section{Recommendation}

It is recommended that future researches should be done using a larger sample size and integrated planning measures are required to collect valuable data and information in order to raise awareness among water resource planners, policymakers, and the general population.

\section{References}

Abdilatif, M. H., Onono, J. O., \& Mutua, F. K. (2018). Analysis of pastoralists' perception on challenges and opportunities for sheep and goat production in Northern Kenya. Tropical Animal Health and Production, 50(7), 1701-1710. https://doi.org/10.1007/s11250-018-1613-8

Abdulatife, M., \& Ebro, A. (2015). Assessment of Pastoral Perceptions towards Range and Livestock Management Practices in Chifra District of Afar Regional State , Ethiopia. Forest Research, 4(2), 44. https://doi.org/10.4172/2168-9776.1000144

Adem, A., \& Bewket, W. (2011). A Climate Change Country Assessment Report for Ethiopia. In Forum for Environment (on behalf of ECSNCC) (Issue August).

Al-Ramamneh, D., Gerken, D. M., \& Riek, A. (2011). Effect of shearing on water turnover and thermobiological variables in German blackhead mutton sheep. Journal of Animal Science, 89(12), 4294-4304. https://doi.org/10.2527/jas.2011-3982

Amenu, K. (2013). Assessment of water sources and quality for livestock and farmers in the Rift Valley area of Ethiopia: Implications for health and food safety. In Hohenheim, Germany: University of Hohenheim.

Araújo, G. L. D., Voltolini, T. V., Chizzotti, M. L., Turco, H. N. and, \& Carvalho, F. R. . (2010). Water and small ruminant production. Revista Brasileira de Zootecnia, 29, 326-336.

Ayenew, T. (2007). Water management problems in the Ethiopian rift: Challenges for development. Journal of African Earth Sciences, 48(2-3), 222-236. https://doi.org/10.1016/j.jafrearsci.2006.05.010

Berhanu, W., \& Fayissa, B. (2010). Analysis of the Household Economy and Expenditure Patterns of a Traditional Pastoralist Society in Southern Ethiopia.

Bishu, K., O’Reilly, S., Lahiff, E., \& Steiner, B. (2012). Cattle farmers' perceptions of risk and risk management strategies. Economic Policy, 2116, 0-33.

CSA (Central Statistic Authority). (2021). Federal Democratic Republic of Ethiopia Central Statistical Agency Agricultural Sample Survey 2020/21 [2013 E.C.], Volume II. Report on Livestock and Livestock Characteristics (Private Peasant Holdings), Addis Ababa, Ethiopia: Vol. II (Issue March).

Devendra, C. (2001). Smallholder Dairy Production Systems in Developing Countries : Characteristics, Potential and Opportunities for Improvement - Review. In Asian-Australasian Journal of Animal Sciences (Vol. 14, Issue 1, pp. 104-113). Asian-Australasian Association of Animal Production Societies. https://doi.org/10.5713/ajas.2001.104

Dinka, M. (2012a). Analysing decadal land use/cover dynamics of the Lake Basaka catchment (Main Ethiopian Rift) using LANDSAT imagery and GIS. Lakes and Reservoirs: Research and Management, 17(1), 11-24. https://doi.org/10.1111/j.1440-1770.2012.00493.x

Dinka, M. (2012b). Analysing the extent (size and shape) of Lake Basaka expansion (Main Ethiopian Rift Valley) using remote sensing and GIS. Lakes and Reservoirs: Research and Management, 17(2), 131-141. https://doi.org/10.1111/j.1440-1770.2012.00500.x

Dinka, M. O. (2017). Lake Basaka Expansion: Challenges for the Sustainability of the Matahara Irrigation Scheme, Awash River Basin (Ethiopia). Irrigation and Drainage, 66(3), $305-315$. https://doi.org/10.1002/ird.2114

Fito, A. U. B. A. J. (2019). Spatial and seasonal variation of lake water quality: Beseka in the Rift Valley of Oromia region, Ethiopia. International Journal of Energy and Water Resources, 0123456789, 1-8. https://doi.org/10.1007/s42108-019-00050-8

Fuad, A., \& W.Michael, G. (2019). Analysis of Physicochemical Properties of Lake Beseka; "The Ever Growing Lake of Ethiopia"s Great Rift Valley." Elixir Applied Chemistry, 127, 52683-52687. https://en.wikipedia.

Funk, C., Rowland, J., Eilerts, G., Kebebe, E., Biru, N., White, L. and, \& Galu, G. (2012). A Climate Trend Analysis of Ethiopia. US Geological Survey, Fact Sheet, 3053.

Gebeyehu, A., Hundessa, F., Umeta, G., Muleta, M., \& Debele, G. (2013). Assessment on challenges and opportunities of goat farming system in Adami Tulu, Arsi Negelle and Fantale districts of Oromia Regional 
State, Ethiopia. African Journal of Agricultural Research, 8(1), 26-31. https://doi.org/10.5897/AJAR12.1568

Jeppesen, E., Meerhoff, M., Davidson, T. A., Trolle, D., Søndergaard, M., Lauridsen, T. L., Beklioğlu, M., Brucet, S., Volta, P., González-Bergonzoni, I., \& Nielsen, A. (2014). Climate change impacts on lakes: An integrated ecological perspective based on a multi-faceted approach, with special focus on shallow lakes. Journal of Limnology, 73(1 SUPPL), 88-111. https://doi.org/10.4081/jlimnol.2014.844

Jiménez Cisneros, B. E., Oki, T., Arnell, N. W., Benito, G., Cogley, J. G., Döll, P., Jiang, T., Mwakalila, S. S., Kundzewicz, Z., \& Nishijima, A. (2015). Freshwater resources. In Climate Change 2014 Impacts, Adaptation and Vulnerability: Part A: Global and Sectoral Aspects. https://doi.org/10.1017/CBO9781107415379.008

Klemperer, S. L., \& Cash, M. D. (2007). Temporal geochemical variation in Ethiopian Lakes Shala, Arenguade, Awasa, and Beseka: Possible environmental impacts from underwater and borehole detonations. Journal of African Earth Sciences, 48(2-3), 174-198. https://doi.org/10.1016/j.jafrearsci.2006.10.006

Komwihangilo, D. M., Sendalo, D. S. C., Lekule, F. P., Mtenga, L. A., \& Temu, V. K. (2001). Farmers' knowledge in the utilisation of indigenous browse species for feeding of goats in semi arid central Tanzania. Livestock Research for Rural Development, 13(6), 1-7.

Lemessa, A. (2011). GIS and Remote Sensing Based Malaria Risk Mapping In Fentalle Woreda, East Shoa Zone, Ethiopia. In Addis Ababa University.

Masters, D. G., Benes, S. E., \& Norman, H. C. (2007). Biosaline agriculture for forage and livestock production. Agriculture, Ecosystems and Environment, 119(3-4), 234-248. https://doi.org/10.1016/j.agee.2006.08.003

Mcgregor, B. A. (2004). The use and macro-mineral content of saline water for goat production The use and macro-mineral content of saline water for goat production. South African Journal of Animal Science, 15-19.

Mdletshe, Z. M., Chimonyo, M., Marufu, M. C., \& Nsahlai, I. V. (2017). Effects of saline water consumption on physiological responses in Nguni goats. Small Ruminant Research, 153, $209-211$. https://doi.org/10.1016/j.smallrumres.2017.06.019

Mdletshe, Zwelethu Mfanafuthi, Ndlela, S. Z., Nsahlai, I. V., \& Chimonyo, M. (2018). Farmer perceptions on factors influencing water scarcity for goats in resource-limited communal farming environments. Tropical Animal Health and Production, 50(7), 1617-1623. https://doi.org/10.1007/s11250-018-1603-x

NRC. (2007). National Research Council. Nutrient Requirements of Small Ruminants. Sheep, Goats, Cervids, and New World Camelids. In National Academy Press, Washington, DC. https://doi.org/10.17226/11654.

Pantuliano, S., \& Pavanello, S. (2009). Taking Drought into Account: Addressing Chronic Vulnerability Among Pastoralists in the Horn of Africa. HPG Policy Brief, 8.

Solomon, G., Hans, K., \& Arendonk, J. A. M. van. (2010). Participatory definition of breeding objectives and selection indexes for sheep breeding in traditional systems. Livestock Science, 128(1-3), 67-74. https://doi.org/10.1016/j.livsci.2009.10.016

Squires, V. (1998). Water and its functions, regulation and comparative use by ruminant livestock. The Ruminant Animal Digestive Physiology and Nutrition, 217-226.

Tadesse, D., Urge, M., Animut, G., \& Mekasha, Y. (2014). Perceptions of households on purpose of keeping, trait preference, and production constraints for selected goat types in Ethiopia. Tropical Animal Health and Production, 46(2), 363-370. https://doi.org/10.1007/s11250-013-0497-x

Wagesho, N., Goel, N. K., \& Jain, M. K. (2012). Investigation of non-stationarity in hydro-climatic variables at Rift Valley lakes basin of Ethiopia. Journal of Hydrology, 444-445, 113-133. https://doi.org/10.1016/j.jhydrol.2012.04.011

Woldetsadik, D., Drechsel, P., Keraita, B., Itanna, F., \& Gebrekidan, H. (2018). Farmers' perceptions on irrigation water contamination, health risks and risk management measures in prominent wastewater-irrigated vegetable farming sites of Addis Ababa, Ethiopia. Environment Systems and Decisions, 38(1), 52-64. https://doi.org/10.1007/s10669-017-9665-2

Yousfi, I., \& Ben Salem, H. (2017). Effect of Increasing Levels of Sodium Chloride in Drinking Water on Intake, Digestion and Blood Metabolites in Barbarine Sheep = Effet de Niveaux Croissants de Chlorure de Sodium dans l'Eau d'Abreuvement sur l'Ingestion, la Digestion et les Métabolites Sa. Annales de l Inrat, 90(90), 202-214. https://doi.org/10.12816/0040329 
Table 1. Households' socio-economic characteristics of sample respondents

\begin{tabular}{lllll}
\hline HH Characteristics & & Lake-users (\%) & River-users (\%) & Total (\%) \\
\hline Sex & Male & 68.4 & 63.2 & 65.8 \\
Age & Female & 31.6 & 36.8 & 34.2 \\
& Below 18 & 5.3 & 0.0 & 2.6 \\
& $19-30$ & 42.1 & 47.4 & 44.7 \\
& $31-50$ & 26.3 & 39.5 & 32.9 \\
Marital Status & Above 50 & 26.3 & 13.2 & 19.7 \\
& Married & 63.2 & 65.8 & 64.5 \\
Educational level & Single & 21.1 & 15.8 & 18.4 \\
& Divorce & 15.8 & 18.4 & 73.7 \\
Production systems & Illiterate & 68.4 & 78.9 & 18.4 \\
\multirow{2}{*}{ Source of income } & Grade 1-7 & 21.1 & 15.8 & 7.9 \\
& Grade 8-12 & 10.5 & 5.3 & 81.6 \\
& Pastoralists & 84.2 & 78.9 & 18.4 \\
& Agropastoral & 15.8 & 21.1 & 19.7 \\
\hline
\end{tabular}

Source: survey, 2019; HH: household

Table 2. Sources and frequency of drinking water

\begin{tabular}{lllll}
\hline \multirow{2}{*}{ Seasons } & & \multicolumn{2}{l}{ Lake Basaka water (\%) } & Overall \\
\cline { 2 - 4 } Rain & Source of water & Users & Non-users & 71.0 \\
\multirow{2}{*}{ Post-rain } & River & 42.1 & 100 & 29.0 \\
& Lake & 57.9 & 0.0 & 65.8 \\
Cool dry & River & 31.6 & 100 & 34.2 \\
& Lake & 68.4 & 0.0 & 50.0 \\
Hot dry & River & 0.0 & 100 & 50.0 \\
& Lake & 100 & 0.0 & 50 \\
Distance of water sources & River & 0.0 & 100 & 50 \\
& Lake & 100 & 0.0 & 25 \\
& $<1 \mathrm{~km}$ & 44.7 & 5.3 & 47.4 \\
\multirow{2}{*}{ Frequency of watering } & $1 \mathrm{~km}-3 \mathrm{~km}$ & 39.5 & 55.3 & 21.1 \\
& 3km - 5km & 15.8 & 26.3 & 6.6 \\
& $>5 \mathrm{~km}$ & 0.0 & 13.2 & 51.3 \\
& Free available & 50 & 52.6 & 28.9 \\
\hline
\end{tabular}

Source: survey, 2019; \%: percentage; km: kilometre. 
Table 3 . Households' perception of the seasonality of water scarcity and quality

\begin{tabular}{|c|c|c|c|c|}
\hline \multirow{2}{*}{ Parameters } & \multirow[b]{2}{*}{ Responses } & \multicolumn{3}{|c|}{ Lake Basaka water (\%) } \\
\hline & & Users & Non-users & Overall \\
\hline \multicolumn{5}{|l|}{ Water scarcity period } \\
\hline \multirow[t]{2}{*}{ Rain } & Perceived & 23.7 & 13.3 & 17.1 \\
\hline & Not-perceived & 76.3 & 86.7 & 80.9 \\
\hline \multirow[t]{2}{*}{ Post-rain } & Perceived & 60.5 & 26.7 & 45.6 \\
\hline & Not-perceived & 39.5 & 73.3 & 54.4 \\
\hline \multirow[t]{2}{*}{ Cool dry } & Perceived & 78.9 & 33.3 & 58.8 \\
\hline & Not-perceived & 21.1 & 66.7 & 41.2 \\
\hline \multirow[t]{2}{*}{ Hot dry } & Perceived & 81.6 & 56.7 & 70.6 \\
\hline & Not-perceived & 18.4 & 43.3 & 29.4 \\
\hline \multicolumn{5}{|l|}{ Water quality period } \\
\hline \multirow[t]{2}{*}{ Rain } & Perceived & 28.9 & 23.3 & 26.5 \\
\hline & Not-perceived & 71.1 & 76.7 & 73.5 \\
\hline \multirow[t]{2}{*}{ Post-rain } & Perceived & 60.5 & 30 & 47.1 \\
\hline & Not-perceived & 39.5 & 70 & 52.9 \\
\hline \multirow[t]{2}{*}{ Cool dry } & Perceived & 73.7 & 43.3 & 60.3 \\
\hline & Not-perceived & 26.3 & 56.7 & 39.7 \\
\hline \multirow[t]{2}{*}{ Hot dry } & Perceived & 65.8 & 60 & 63.2 \\
\hline & Not-perceived & 34.2 & 40 & 36.8 \\
\hline
\end{tabular}

Source: survey, 2019.

Table 4. Perception of water salinity trend of lake Basaka quality

\begin{tabular}{lllll}
\hline Parameters & & \multicolumn{3}{l}{ Lake Basaka Water (\%) } \\
\cline { 2 - 4 } & & Users & Non-Users & Overall \\
\hline Suitable of lake Basaka for livestock & Yes & 0 & 47.4 & 23.7 \\
& No & 100 & 52.6 & 76.3 \\
Do you think lake Basaka has salt? & Yes & 100 & 57.9 & 78.9 \\
Factors of water salinity of lake Basaka & No & 0 & 42.1 & 21.1 \\
& Natural & 81.6 & $86.8)$ & 84.2 \\
\hline Salinity trend of lake Basaka water & Human & 18.4 & 13.2 & 15.8 \\
\hline Increasing & & & & 39.5 \\
& Perceived & 26.3 & 52.6 & 60.5 \\
Decreasing & Not perceived & 73.7 & 47.4 & 71.1 \\
& Perceived & 79 & 68.4 & 28.9 \\
\hline Seasonal variation of Lake Basaka water salinity & Not perceived & 21 & 31.6 & \\
\hline Rain season & & & & 25 \\
Post-rain Season & Increasing & 21.1 & 28.9 & 75 \\
Cool dry Season & Decreasing & 78.9 & 71.1 & 35.5 \\
Hot dry Season & Increasing & 28.9 & 42.1 & 64.5 \\
& Decreasing & 71.1 & 57.9 & 73.7 \\
\hline Source: survey, & Increasing & 78.9 & 68.4 & 26.3
\end{tabular}

Source: survey, 2019; \%: percentage 
Table 5. Effects of drinking Lake Basaka water on livestock health and species

\begin{tabular}{|c|c|c|c|c|}
\hline \multirow[b]{2}{*}{ Effect of lake Basaka water } & \multirow[b]{2}{*}{ Response } & \multicolumn{3}{|c|}{ Lake Basaka Water (\%) } \\
\hline & & $\begin{array}{l}\text { User } \\
\mathrm{S}\end{array}$ & $\begin{array}{l}\text { Non- } \\
\text { Users }\end{array}$ & $\begin{array}{l}\text { Overal } \\
1\end{array}$ \\
\hline \multirow[t]{2}{*}{ Livestock health's } & Perceived & 100 & 100 & 100 \\
\hline & Not perceived & 0 & 0 & 0 \\
\hline \multirow[t]{2}{*}{ Sheep and Goat } & Perceived & 100 & 89.5 & 94.7 \\
\hline & Not perceived & 0 & 10.5 & 5.3 \\
\hline \multirow[t]{2}{*}{ Cattle } & Perceived & 100 & 65.8 & 82.9 \\
\hline & Not perceived & 0 & 34.2 & 17.1 \\
\hline \multirow[t]{2}{*}{ Camel } & Perceived & 47.4 & 39.5 & 43.4 \\
\hline & Not perceived & 52.6 & 60.5 & 56.6 \\
\hline \multirow[t]{3}{*}{ Tolerance of livestock species } & Sheep and goat & 31.6 & 26.3 & 28.9 \\
\hline & Cattle & 7.9 & 10.5 & 9.2 \\
\hline & Camels & 60.5 & 63.2 & 61.8 \\
\hline \multicolumn{5}{|l|}{ Production parameters } \\
\hline \multirow[t]{2}{*}{ Reduced Growth } & Perceived & 84.2 & 60.5 & 72.4 \\
\hline & Not-perceived & 15.8 & 39.5 & 27.6 \\
\hline \multirow{2}{*}{ Reduced milk yield } & Perceived & 81.6 & 71.1 & 76.3 \\
\hline & Not-perceived & 18.4 & 28.9 & 23.7 \\
\hline \multirow[t]{2}{*}{ Emaciation } & Perceived & 100 & 73.7 & 86.8 \\
\hline & Not-perceived & 0 & 26.3 & 13.2 \\
\hline \multirow{3}{*}{$\begin{array}{l}\text { Which small ruminant is more adapted to drinking lake } \\
\text { Basaka water? }\end{array}$} & Sheep & 13.2 & 18.4 & 15.8 \\
\hline & Goat & 68.4 & 55.3 & 61.2 \\
\hline & Both & 18.4 & 26.3 & 22.4 \\
\hline
\end{tabular}

Source: survey, 2019; \%: percent 